\title{
The necessity of socio-ecological modification of two-tier economic model of secondary resources management in Ukraine
}

\author{
Larysa Hrytsenko
}

Doctor of Economics, Associate Professor, Department of Finance and Credit, Sumy State

University, Ukraine

\section{Mykola Petrushenko}

\author{
Doctor of Economics, Associate Professor, Department of Management, Sumy State University, \\ Ukraine
}

\section{Katherina Daher}

Ph.D., Assistant Professor at Business School, Lebanese International University, Beirut, Lebanon

(C) The Authors, 2017. This article is published with open access at ARMG Publishing.

\begin{abstract}
The problems of effective use of secondary resources, as well as the overall problem of managing them at the level of the national economy in the context of separate sectors and enterprises remain relevant for countries with transition economy for more than a quarter of a century. However, in the context of management situations modeling, including those with regard to more efficient use of secondary resources, the issue, mentioned above, requires further actualization and its solutions.

The article discloses an ecological approach to the study of socio-economic relations, in particular to the manufacturing processes. It is shown that the scale of use of the environment and the structure of the industrial production established in Ukraine placed it among the countries with the highest absolute and specific indicators of formation and accumulation of toxic waste; a situation with them remains critical today. As a tool for issues optimization associated with the secondary resources and waste, the industry model is considered, in which the criterion of an optimality is the maximum excess of the economic result over the costs for the use of secondary raw materials and the elimination of social, ecological and economic damage due to waste generation.

It is proved that the protection of the environment and public health from the negative impact of waste is an urgent task and a priority principle of the policy on the way of sustainable development of the state. The socioecological modification of economic-mathematical model of secondary resources management is proposed: environmental effect is represented as the value of prevented damage from environmental waste pollution; social effect is represented as the sum of the effects from improving the utilization of the labor force due to the reduced morbidity from social insurance savings and reduction of costs in healthcare.
\end{abstract}

Keywords: secondary resources, two-tier economic model, socio-ecological modification, management, Ukraine.

JEL Classification: Q01, Q32, C51.

\section{Introduction}

The problems of effective use of secondary resources, as well as the overall problem of managing them at the level of the national economy in the context of separate sectors and enterprises remain relevant for countries with developing or transition economy for more than a quarter of a century. Due to the fact that Ukraine, like most countries in the world, moves in its development on the principles of sustainability and balance, which are declared in the international policy document "Agenda - XXI", as well as in its national equivalents, socioecological component of economic transformation is an integral part of a common factor of evolutionary vector of the country. However, in the context of the relevance of scientific research in particular, in management situations modeling, including those with regard to more efficient use of secondary resources, the issue, mentioned above requires further actualization and its solutions both on theoretical and on practical planes.

Among the scientific papers, in which a study of economic and related ecological and social issues of secondary resources management was carried out as well as the waste in industrial production, can be mentioned works of Ukrainian scientists, in particular, O.F. Balatskiy, V.A. Zaytsev, and N.V. Yarosh (1984), Yu.P. Lebedinskiy, Yu.V. Sklyankin, and P.I. Popov (1990), B.V. Burkinskiy, V.N. Stepanov, and 
S.K. Kharichkov (1999), and works of foreign scientists: E.B. Hosoda (2012), M. Cote, W.-R. Poganietz, and L. Schebek (2015), N. Gregson, and M. Crang (2015) and many others. Thus, the article by E.A. Olivetti, G.G. Gaustadt, F.R. Field, and R.E. Kirchain (2011) analyses the increased use of secondary and renewable resources that will likely be key toward achieving sustainable materials use. The work by N.M.P. Bocken, I. de Pauw, C. Bakker, and B. van der Grinten (2015) develops a framework of strategies to guide designers and business strategists in the move from a linear to a circular economy, and opens up a future research agenda for the circular economy. The paper of C.A. Velis (2015) analyses linkages between circular economy and global secondary material supply chains. In spite of detailed analysis and extensive results of these and other relevant studies, the questions of the account of socio-ecological factors in the context of economic and mathematical modeling of management processes of secondary resources require further development and improvement.

The purpose of a given research is the rationale for necessity of theoretical positions formation of socioecological modification of two-tier secondary resources management model at the sectoral level of the Ukrainian economy.

\section{The main results of the study}

Any sphere of public life, in particular, economic, associated with various resources which consumption will inevitably arise the need to resolve environmental issues, that in practice with the terminology regard associated with such concepts as the ecological approach, ecological criterion, etc.

A general scientific approach, with the orientation primarily on the research and reflection of relations and interactions of organisms and a human with the environment is meant under the ecological approach [13].

Ecological criterion is an attribute, on the basis of which the evaluation, identification and classification of ecological systems, processes and phenomena are making. The question about this criterion is very important for the ecological rationale for the project, environmental planning, forecasting, rationing, environmental expertise, ecological and economic evaluation. Ecological criterion can be nature-preserving (conservation of ecosystem integrity, species of organisms, their habitats, etc.), anthropoecological (impact on humans, their population) and economic, up to the impact on the entire system "nature - society" [13].

Characterizing the crisis ecological situation on a global scale, it should be noted that all natural mediums felt the significant pollution. The present state of the environment ascertains the fact of large-scale technogenic impact on air, water, soil and all wildlife. Thus, in the 80 -s of the last century $400-600 \mathrm{~kg}$ of industrial waste per capita were formed annually in the developed countries of the world and, taking into account the waste in the largest branches of economy, the figure was 4-6 tons. Household waste was formed no less - annually on each inhabitant of the planet and accounted from 150 to $600 \mathrm{~kg}$ [8, p. 54-55]. The actuality of the problem of production waste and household waste is also emphasized in the work [7]. Particularly, it is indicated that more than 25 billion tons of waste was accumulated, the area to store them occupies 160 thousand hectares and increases annually by 3-6 thousand hectares, which limits the resource base for agriculture and urban expansion.

In Ukraine a difficult ecological situation is complicated by the presence of painful market transformations and the general crisis state of the economy. In particular, this is about specific form of "ecological and economic effects of a boomerang," the essence of which is that the boundless economy breaks down the nature and its destruction has a negative impact on the economy [2, p. 13]. Indicated specificity consists in the fact that in spite of a general decline in production of our country, the environment still feels a considerable anthropogenic pressure.

In this regard, Ukraine's transition to sustainable socio-ecological balanced development can be divided into three stages: the survival (improving living standards), modernization (production-technological and socioeconomic, which allows to create a modern post-industrial society), ecological reconstruction (rehabilitation of environmentally unsuitable areas, renovation and reconstruction of damaged ecosystems) [4].

Before we consider in more detail the first of above stages at which our country currently is in, they recall the situation that prevailed before the transformation of the economic system in Ukraine, in particular, by industrial incision, that was structurally caused by a former system of the national economy. The expediency of this consideration is explained by the fact that due to the inert processes of restructuring the economic processes the overall situation in domestic production has changed little over the past quarter of the century. 
Until 1990, in Ukraine, the largest amounts of waste were formed in the sectors of mineral raw materials complex, which included mining and enrichment plants, a great number of industries including coal, black and nonferrous metallurgy, chemical industry, manufacturers of construction materials and constructions, etc. In these industries $70-75 \%$ of the total volume of waste were formed that meant about 8.5 tons of solid waste annually. Reserves for their use in the economy were significant. In the $80-$ s, only $6-7 \%$ of this waste found application [8, p. 57].

Waste disposal problems in the chemical industry differed by its own specificity. It consisted, first of all in an exceptional variety of raw materials involved in the processing, in the specifics of production processes themselves. In the 80 s the nomenclature of chemical industry products totaled about 70 thousand items as a whole, and the number of generated types of waste amounted to several thousand items, which varied in composition, in methods of disposal, in impact on the environment. Therefore, the decision of the problems of waste disposal did not have any general principles. We can only indicate the fact that the wastes with close properties to raw materials and finished products were used within the industry, while the use of all other wastes wore an interdisciplinary nature. Additional difficulties conditioned by the small amounts of formation of many types of waste, which led, on the one hand, to the inefficiency of the creation of capacities for disposal at separate enterprises and, on the other hand, - the need to solve complex problems of transportation of such wastes in case of creation of large-scale specialized production.

However, the work carried out in the industry enables the use of a certain part of wastes and the replacement of scarce raw materials and materials. Thus, iron vitriol, chalk of fine fractions, the remnants of soda production are widely used by enterprises of construction and agricultural sectors and other sectors of the national economy. Of course, it is important to pay main attention to the large tonnage wastes disposal which provides the greatest economic and ecological effects. Such wastes, along with the above include phosphogypsum, sulfur, chromium, zinc and other sludges. It is noteworthy, that in the volumes of the hundreds of thousands of tons formation, they can generally be used in other industries.

By 1992, the total volume of creation of the wastes was relatively stabilized. At the same time, structural changes reflected in the relative reduction of one of their group (metallurgical slag, ash-containing sludge, wood waste) and increased in other (phosphogypsum, waste paper, polymers, solid domestic waste) took place. However, most of the wastes is piled on the earth's surface in the form of waste heaps and landfills of all sorts. Each year in the surface repositories around 0.9-1.0 billion tons of solid waste is stockpiled, and the total of their conglomeration on the territory of Ukraine on minimum estimate exceeded 15 billion tons. more than 150 thousand hectares of land employs under the placement of waste. The burning of waste heaps, dust formation above the surface of sludge storage tanks, groundwater salinity has a detrimental effect on the environment, degrading land, deteriorating health of the population.

The specific load on the territory at the expense of solid waste had reached in some regions of Ukraine, especially in the industrial Dnieper area and Donbas, 8-18 thousand tons $/ \mathrm{km}^{2}$. On average in Ukraine the creation of mining waste was about 3 thousand tons $/ \mathrm{km}^{2}$. These values were exceeded in Dnipro, Donetsk, Lugansk, Zaporizhiia, Poltava regions and in the Republic of Crimea [11].

As of 2015 the general economic downward trend in output is retained that is a premise to a reduction in funding for environmental measures and results in lower level of use of wastes (Table 1) [15]. As a result in Ukraine environmental problems associated with the accumulation of toxic waste, among which the most dangerous are those that contain metals and unfit for use pesticides are exacerbated.

Table 1. Availabilityof wastes in Ukraine by hazard category, 2000-2015, thousands tons

\begin{tabular}{|l|c|c|c|c|c|c|}
\hline \multicolumn{1}{|c|}{ Waste } & 2000 & 2005 & 2010 & 2013 & 2014 & 2015 \\
\hline Total & 26244.1 & 21674.0 & 13267455.0 & 15167368.9 & 12205388.8 & 12505915.8 \\
\hline I class of danger & 149.1 & 38.6 & 25.8 & 18.2 & 15.0 & 14.8 \\
\hline II class of danger & 1685.2 & 1846.9 & 2270.7 & 349.4 & 223.5 & 278.3 \\
\hline III class of danger & 24409.8 & 19788.5 & 13939.8 & 12274.0 & 11757.5 & 11761.9 \\
\hline IV class of danger & $\ldots$ & $\ldots$ & 13251218.7 & 15154727.3 & 12193392.8 & 12493860.8 \\
\hline
\end{tabular}

Often conditions of conservation and waste disposal in Ukraine do not meet the sanitary requirements, that leads to contamination of surface and ground water, soil, air. The majority of regions of Ukraine do not have any landfills for conservation and waste disposal. Investigations of waste disposal landfills showed the presence of about 2.760 of objects of wastes localization in Ukraine with an area of over 30 thousand hectares. 
The scale of environmental management and established structure of the industrial production have placed Ukraine among the countries with the highest absolute and specific indicators of production and accumulation of toxic industrial and household wastes. The annual volume of wastes which fell on $1 \mathrm{~km}^{2}$ of area of Ukraine 6.5 times higher than in the US and 3.2 times higher than in the EES. According to the scientists [2, p. 60] "the accumulation of waste production and consumption on the background of the low level of recycling and economic use in Ukraine leads to greater environmental pollution, increase an anthropogenic pressure on natural resources, reduction of socio-ecological stability of the regions development".

The reasons of these and other deficiencies are the following: cross-sectoral nature of most environmental problems, lack of targeted investments, lack of sufficient financial resources to solve the problem that is exacerbated by the overall unfavorable investment climate in the regions; high resource intensity of production and the waste capacity of economic activity, inadequate pricing for the products of secondary resources; lack of proper waste management system in the conditions of transformation of the economy (the administrative and legal mechanism, the state and regional strategies and program-targeted planning, normative base, etc.) [2, p. 60; 29].

The only way to ensure a more secure and prosperous future is the solution of environmental problems and economic development in a complex and coherent manner, in particular, the effective tools to stimulate entrepreneurship in the field of use of wastes, the formation of the market of secondary resources, the introduction of new resource-saving and environmentally friendly technologies.

Conceptually, the main principles of public policy in waste management sphere that are defined at the legislative level; the priority is the protection of the environment and human health from the adverse influence of waste; ensuring a prudent use of raw material and energy resources, as well as science-based harmonization of environmental, economic and social interests of society with respect to formation and the use of waste in order to ensure its sustainable development [9;12].

So, the arguments presented above demonstrate the need for environmental and wider socio-ecological modification of secondary resource management model at the sectoral level of the national economy.

Let us consider some of the technological and organizational features of resource consumption in an industrial plant, in view of concrete solutions which are taken while optimizing of natural resources use. The main technological challenge of an industrial enterprise in terms of increasing production efficiency and reducing the level of the waste placement is the creation of low-waste production systems. Big modern diversified industrial enterprise is characterized by diverse nomenclature of consumed raw materials, manufactured products and generated waste.

The subject of optimization of resource use at the enterprise is its material balance: the analysis of the level of use of raw materials in all production associations is carried out, the recommendations for improvement are given and also the cost-effectiveness of production with increasing the level of use of raw materials to the recommended is assessed.

In the conditions of multivariance of technical decisions on waste recycling, potential customers, a large range of secondary resources, causing the possibility of their interchangeability, joint use, as well as the availability of economic and environmental constraints, the identification of the optimal variant of planning and organizing at the enterprise level a low-waste production system with the inclusion of the set subsystems is impossible without the use of economic-mathematical modeling methods.

A number of techniques for calculating the economic cost effectiveness in environmental protection activities and evaluation of economic damage from environmental pollution (techniques developed by doctors of economics O.F. Balatsky, K.G. Hoffmann, A.A. Gusev et al.) were proposed by scholars-economists of our country during recent decades. The phenomena at the macro level were investigated throughout the country or administrative-territorial formations. Furthermore, the elements used in the study of the problems at the enterprise level, particularly a modified model below, has been developed on the basis of the proposals of an economist N.V. Yarosh [1, 10, 16, 17].

As it is known, the system of state regulation of nature management reveals two opposing tendencies: centralization of functions of nature management and enhancing the role of the main control unit, which is associated with the specificity of environmental and related social problems. 
Under conditions of incomplete resolution of the contradiction between the sectoral interests and the interests of individual enterprise, optimization calculations should be carried out in two directions.

The sectoral optimization model is the basis for the formation of the planned regulations and serves as the foundation for making changes in economic accounting relationships in order to eliminate existing contradictions. Acknowledging the priority of sectoral model, it should be noted that a particular enterprise is guided primarily by the economic accounting relationships conditions in which it is placed. In this regard it is also required to optimize a low-waste technology system for economic accounting enterprise parameters. Thus, a two-tier model is needed.

The criterion of optimality is the maximum exceeding the economic result over the costs, contributing to it. In expanded form the sectoral criterion of optimality has the following form:

$$
\begin{aligned}
E & =\sum_{i=1}^{n} Q_{i j} \sum_{j=1}^{m} \delta_{i j}\left[\left(C_{1 i j}+C_{2 i j}+C_{3 i j}+C_{4 i j}\right)+\sum_{k=1}^{l}\left(D_{i j k}^{h}+D_{i j k}^{l}+D_{i j k}^{g}\right)+D_{i j}^{\prime}\right]- \\
& -\sum_{i=1}^{n} Q_{i j} \sum_{j=1}^{n} \delta_{i j}\left[\left(C_{i j}^{c o n}+\sum_{\tau=1}^{\lambda} C_{i j \tau}^{t r}+C_{i j}^{r e s}\right)\right]-\sum_{i=1}^{n} Q_{i j}\left(1-\sum_{j=1}^{m} \delta_{i j}\right) D_{i j}^{u n d} \rightarrow \max ,
\end{aligned}
$$

where $i, n$ - the sequence number and the total number of considered secondary resources $(i=1, \ldots, n)$;

$j, m$ - the sequence number and the number of directions of using of secondary resources $(j=1, \ldots, m)$;

$k, l$ - the sequence number and the total number of secondary resources, forming in the production of interchangeable $i$ secondary resource on $j$ variant of primary raw materials $(k=1, \ldots, l)$;

$\tau, \lambda$ - the sequence number and the total number of consumers of secondary resources and products from them $(\tau=1, \ldots, \lambda)$;

$Q_{i j}$ the mass of secondary resource $i$ used for direction $j$;

$C_{1 i j}-$ the possible economy of resulted consumer costs by using secondary resources or their products, $\mathrm{UAH} / \mathrm{tons}$;

$C_{2 i j}$ the possible economy of resulted costs for production replaceable products from of primary raw materials, UAH/tons;

$C_{3 i j}$ - the possible economy of resulted costs for the removal, destruction, maintenance of waste generated in the production of replaceable primary raw materials, $\mathrm{UAH} / \mathrm{tons}$;

$C_{4 i j}$ - the possible economy of other resulted costs (caused by territorial redistribution of production, changes in regional planning, the industry reallocation of labor resources, savings of the resulted costs for the reproduction of stocks of raw materials, foreign trade effect, etc.);

$D_{i j k}$ - the averted economic damage as a result of replacement of primary raw materials, the economic damage caused by environmental pollution of the waste $k$ (on the variant) of embodiment $j$ with the use of waste $i$, $\mathrm{UAH} /$ tons of waste;

$D_{i j}^{\prime}$ - the averted economic damage through the use of waste $k$ of embodiment $j$ the economic damage caused by it as a result of environmental contamination when the waste is not used, UAH/tons;

$D^{u n d}$ - the residual economic damage caused by underutilized part of the waste $i$ of embodiment $j$, UAH/tons; $C^{c o n}{ }_{i j}$ - the additional costs of the consumer of secondary resources or their production with the replacement of traditional raw material on the secondary resource $i$ of embodiment $j$, UAH/tons;

$C^{t r}{ }_{i j} \tau$ - the transport costsof the consumer $\tau$ by using the secondary resource $i$ of embodiment $j, \mathrm{UAH} /$ tons;

$C^{r e s}{ }_{i j}$ - the resulted costs for preparing to the implementation or the processing of secondary resources $i$ of embodiment $j$ by the producer of secondary raw materials, $\mathrm{UAH} /$ tons;

$\delta_{i j}$ - the proportion of secondary resource $i$, used of embodiment $j$.

The restriction is imposed in the given economic and mathematical model:

$Q_{i j} \leq A_{i j}$, 
where $A_{i j}$ - the constraint on the use of secondary resource $i$ of embodiment $j$, conditioned by the need of the secondary resource or its products.

At the enterprise level a model based on its economic parameters can be implemented. Consequently, the criterion of optimality in this model is the profit:

$\ni=\sum_{i=1}^{n} Q_{i} \sum_{j=1}^{m} \delta_{i j}\left[\left(P_{i j}-C_{i j}\right)+\Delta C_{i j}+\Delta E_{i j}-E C_{i j}^{c a p}\right] \rightarrow \max$,

where $P_{i j}$ - the price of selling secondary resource and products from the secondary resource $i$ of embodiment $j, \mathrm{UAH} /$ tons;

$C_{i j}$ - the current costs for the secondary resource preparation for sale or for its production $i$ of embodiment $j$, $\mathrm{UAH} /$ tons;

$\Delta C_{i j}$ - the cost savings for removal, destruction, waste keeping, $\mathrm{UAH} /$ tons;

$\Delta E_{i j}$ - the savings on pollution expenses of the environment, $\mathrm{UAH} /$ tons;

$C^{c a p}{ }_{i j}$ - the capital costs for the preparation of secondary resources for selling or for manufacture of products from the secondary resource $i$ of embodiment $j$, UAH/tons.

In the model, along with the introduction of caused internal economic damage (underproduction of profit due to the increased morbidity of employees, employee turnover, accelerated depreciation of fixed assets, reduction of product quality, etc.), industrial economic damage should be introduced.

In this study, authors are mainly concerned with socio-ecological side of an issue and do not set a goal of a detailed analysis of the economic essence of each of the components in the above model (equations 1-3). For example, actual is the issue of price formation $(P)$ in the field of the sale of products manufactured from secondary resources. Thus, Yu.I. Stadnytskiy in his work [14, p. 179-180] in economic-mathematical forecasting model of the price on secondary resources offers to calculate the cost of production per unit of $j$ consumer with the use of raw materials from the $i$ supplier considering the cost of raw material using the formula:

$C_{i j}^{p r}=\left(P_{i}^{r m}+C_{i j}^{s h i p}\right) \cdot G_{i j}+C_{i j}^{\prime}$,

where $C_{i j}$ - the cost of production per unit of $j$ consumer with the use of raw materials from $i$ supplier (without considering the cost of raw material), $\mathrm{UAH}$;

$C^{p r}{ }_{i j}$ - the cost of production per unit of $j$ consumer with the use of raw materials from $i$ supplier (considering the cost of raw material), UAH;

$C^{\text {ship }}{ }_{i j}$ - the shipping costs (including wastes) from $i$ supplier to $j$ consumer, UAH/tons;

$G_{i j}$ - the amount of cargo (raw materials, semi-finished products or product) of $i$ supplier, needed for the production of goods by $j$ consumer, tons;

$P^{r m}{ }_{i}$ - the price of raw material, UAH/tons.

At the same time it is indicated that the initial value of the price of secondary resources unlike the price of the primary (specially produced for sale) materials may acquire a null or even a minus value. The possibility of negative price is explained by the expediency for the supplier to carry out a full surcharge to the consumer, only not to incur the costs associated with the removal and disposal of waste. It is evident that the value of surcharges (a minus price) should not exceed the potential damage that would arise in the event of non-use of secondary resources.

In a whole the improvement of management of the processes of resource consumption at the micro level in the conditions of market transformations requires in parallel with the mentioned above somewhat different approach. Primarily, in the study of this problem it is necessary to allocate its three components - economic, ecological and social [18].

Ecological and social components of the problem of industrial wastes represent a set of factors that render a significant negative impact on the environment and the social side of the population life. The growth of the territories, occupied by landfills for waste storage, leads to a reduction of land area suitable for economic use, 
has a negative effect on the environment, creates the possibility of technological disasters, polluting the groundwater and the air.

Considering the economic component in the framework of the investment and crediting processes the role of the category of comparative efficiency increaes.

To select among the priority projects, it is important a clear understanding of the relationship between the expenses from the introduction of one or another low-waste manufacturing and the effect that can be achieved as a result:

$$
E_{l w t}=\frac{E_{o}}{O_{e x}}
$$

where $E_{l w t}$ - the effectiveness of the introduction of low-waste technology, UAH/UAH;

$E_{o}$ - the overall effect from introduction of low-waste technology, UAH;

$O_{e x}-$ the overall expenses from introduction of low-waste technology, UAH.

Herewith the overall effect equals the sum of economic, ecological and social effects:

$$
E_{o}=E_{\text {econ }}+E_{\text {ecol }}+E_{s o c} \text {. }
$$

The economic effect $\left(E_{\text {econ }}\right)$ can be calculated as follows:

$$
E_{\text {econ }}=\sum_{i=1}^{n} Q_{i}\left[\left(P_{i}^{w}-C_{i}\right)+\Delta C\right]
$$

where $P^{w}{ }_{i}$ - the wholesale price on products selling $i$ obtained from secondary raw materials, $\mathrm{UAH} /$ tons; $C_{i}$ - the current costs on secondary raw materials preparation and their products $i, \mathrm{UAH} /$ tons;

$Q_{i}$ - the annual volume of finished products $i$ manufactured from secondary raw materials, tons.

$\Delta C$ - the cost saving for removal, destruction, waste keeping, $\mathrm{UAH} /$ tons.

Ecological effect $\left(E_{\text {ecol }}\right)$ - the value of prevented environmental damage caused by environmental pollution:

$$
E_{\text {ecol }}=D_{a v}+Y_{\text {int }} \text {, }
$$

where $D_{a v}$ - the averted economic damage as a result of replacement of primary raw materials to secondary, $\mathrm{UAH}$;

$$
D_{a v}=D_{e x}+D_{i n t},
$$

where $D_{e x}-$ the prevented external damage that caused by polluting enterprise to neighboring economic entities, UAH;

$D_{\text {int }}$ - the prevented internal damage (damage to the enterprise), caused by environmental pollution with the wastes of its own production, UAH;

$D_{\text {prev }}$ - the economic damage that is prevented by the waste disposal, caused by them as a result of environmental contamination if they left unused (if the solid waste disposal sites located within or very close to the industrial plant, i.e., they are their own sources of pollution of the territory of the enterprise, this type of damage is also differentiated at the external and internal), UAH.

$$
D_{\text {prev }}=D_{\text {prev }}^{a}+D_{\text {prev }}^{w}+D_{\text {prev }}^{l}+D_{\text {prev }}^{b},
$$

where $D_{\text {prev }}^{a}$ - an estimate of the value of prevented damage from air pollution in a given region, UAH;

$D^{w}{ }_{\text {prev }}$ - an estimate of the value of prevented damage from water pollution, $\mathrm{UAH}$;

$D_{\text {prev }}^{l}$ - an estimate of the value of prevented damage from soil and land resources pollution, UAH;

$D_{\text {prev }}^{b}$ - an estimate of the value of prevented damage from harming the bioresources, UAH.

Temporal techniques are used for economic damages recalculation.

The social effect is represented by the sum of the effects:

$$
E_{s o c}=E_{l r}+E_{s s}+E_{h},
$$


where $E_{l r}$ - the improvement in the use of labor resources in material production due to a decrease in morbidity of the population, UAH;

$E_{S s}$ - the savings of social insurance resources by reducing morbidity of the population, UAH;

$E_{h}$ - the cost reduction in healthcare by decreasing morbidity of the population, UAH.

The overall costs of industrial enterprises activity with a certain degree of conditionality can be divided into economic, social and ecological:

$$
C_{t}=C_{e c o n}+C_{e c o l}+C_{s o c} .
$$

The social costs $\left(C_{s o c}\right)$ represent the damage caused to human health in relation to the activity of a given production. On the enterprises of chemical industry manufacturing processes which belong to the category of highly dangerous, this component of the cost has a weighty importance and should be considered as the sum of internal ( $C^{i n t}$ soc - damage to human health who involved in harmful manufacture) and external costs $\left(C^{e x}{ }_{s o c}\right.$ -damage to health of the population):

$$
C_{s o c}=C_{s o c}^{\mathrm{int}}+C_{s o c}^{e x t} .
$$

The ecological costs $\left(C_{e c o l}\right)$ can be represented as follows:

$$
C_{e c o l}=D_{i j}^{r e s}+P_{p w}+C_{u s e},
$$

where $D^{r e s}$ ij - the residual economic damage caused by underutilized part of the waste, UAH; $P_{p w}$ - the collection of environmental pollution by placement of waste, UAH;

$C_{u s e}$ - the collection of natural resources use (if new technologies along with the use of secondary resources require the involvement of primary resources), UAH.

The economic costs consist of capital investments, taking into account the amortization and operational costs. The capital costs include the cost for acquisition and construction of new low-waste technologies, as well as the reconstruction or modernization of existing production facilities. The current costs include the cost of maintaining, transportation and disposal of raw materials; fuel costs, energy, water, reagents, and other materials used in technological processes; wages of personnel involved in the given work; current repairs and etc.

In a general view the economic costs can be represented as follows:

$$
C_{\text {econ }}=K_{t} \times E+C_{t} \text {, }
$$

where $K_{t}-$ the capital investments for the introduction of low-waste technology in the $t$ period, UAH;

$E_{-}$- the rate of return on invested capital;

$\overline{C_{t}}-$ the current costs in $t$ period, UAH.

Thus, the result of specific activities on the rationalization of resource consumption must be studied by comparing the costs of its achievement and obtained effects.

\section{Conclusions}

As a result of the conducted research, the following conclusions can be made. First, the features and threats of ecological situation in Ukraine are disclosed, which has developed in connection with the formation of industrial wastes for the past three decades. It is proved that the protection of the environment and public health from the negative impact of waste is an urgent task and a priority principle of the policy on the way of sustainable development of the state.

Secondly, the socio-ecological modification of economic-mathematical model of secondary resources management is proposed: environmental effect is represented as the value of prevented damage from environmental waste pollution; social effect is represented as the sum of the effects from improving the utilization of the labor force due to the reduced morbidity from social insurance savings and reduction of costs in healthcare.

Further studies will be focused on the development of models of management of secondary resources and industrial waste in individual industries of the national economy, especially in the chemical industry, where the question of ecological and economic damage is particularly acute, especially regarding the impact on health of the population. 


\section{References}

1. Balatskiy, O.F., Zaytsev, V.A., Yarosh, N.V. (1984). Malo i bezothodnyie proizvodstva: ekonomicheskaya otsenka i perspektivyi razvitiya [Low- and non-waste production: economic evaluation and development prospects]. Problemy okruzhayuschey sredy i prirodnyh resursov (prilozhenie) [Problems of the Environment and Natural Resources (Annex)], 8, 3-51 (in Russian).

2. Bocken, N.M.P., de Pauw, I., Bakker, C., van der Grinten, B. (2015). Product design and business model strategies for a circular economy. Journal of Industrial and Production Engineering, 33(5), 308-320. Retrieved from doi:10.1080/21681015.2016.1172124.

3. Burkinskiy, B.V., Stepanov, V.N., Kharichkov, S.K. (1999). Prirodopolzovanie: osnovy ekonomikoekologicheskoy teorii [Nature management: the foundations of economic and ecological theory]. Odessa, IPREEI NAN Ukrainy, 350 p. (in Russian).

4. Cote, M., Poganietz, W.-R., Schebek, L. (2015). Quantitative and qualitative dynamic modelling of secondary raw materials from wood products in Germany. Matériaux \& Techniques, 103(1), 8. Retrieved from doi:org/10.1051/mattech/2015001.

5. Gregson, N., Crang, M. (2015). From waste to resource: the trade in wastes and global recycling economies. Annual Review of Environment and Resources, 40, 151-176. Retrieved from doi:10.1146/annurev-environ-102014-021105.

6. Hens, L., Melnik, L., Bunn, E., eds. (1998). Ekonomika prirodopolzovaniya [Environmental Economics]. Kiev, Naukova dumka, 480 p. (in Russian).

7. Hosoda, E.B. (2012). Recycling of waste and downgrading of secondary resources in a classical type of production model. Journal of Economic Structures, 1(7). Retrieved from doi:10.1186/2193-2409-1-7.

8. Kukhar, V. (1998). Poriadok dennyi dlia Ukraiiny na XXI stolittia [Agenda XXI for Ukraine]. Vistnyk NAN Ukrainy, 7-8, 7-15 (in Ukranian).

9. Lebedinskiy, Yu.P., Sklyankin, Yu.V., Popov, P.I. (1990). Resursosberezhenie i Ekologiya [Resource Saving and Ecology]. Kiev, Politizdat Ukrayny, 223 p. (in Russian).

10. Luk'yanikhin, V.A., Petrushenko, N.N. (2004). Ekologicheskiy menedzhment: printsipy i metody [Ecological management: principles and methods]. Sumy, ITD "Universitetskaya kniga", 408 p. (in Russian).

11. Melnik, L.G., Yarosh, N.V. (1981). Effektivnost bezothodnyh tehnologiy [The effectiveness of non-waste technologies]. Vestnik Harkovskogo Politehnicheskogo Instituta, 9(184), 61-64 (in Russian).

12. Natsionalnyiy doklad o sostoyanii okruzhayuschey prirodnoy sredy $v$ Ukraine [National report on the state of the environment in Ukraine] (1992). Kiev, The Ministry of Environmental Protection of Ukraine. 94 p. (in Russian).

13. Olivetti, E.A., Gaustadt, G.G., Field, F.R., Kirchain, R.E. (2011). Increasing secondary and renewable material use: a chance constrained modeling approach to manage feedstock quality variation. Environmental Science \& Technology, 45(9), 4118-4126. Retrieved from doi: 10.1021/es103486s.

14. Petrushenko, N.N. (2003). Sotsialno-psihologicheskiy kontekst ekologo-ekonomicheskih otsenok [Sociopsychological context of ecological and economic assessments]. Vestnik SumGU. Seriya "Ekonomika", 6(52), 158-166 (in Russian).

15. Snakin, V.V. (2000). Ekologiya i ohrana prirody [Ecology and nature protection]. Ed. A.L. Yanshin. Moscow, Academia. 384 p. (in Russian).

16. Stadnytskiy, Yu.I. (1999). Ekonomichni osnovy upravlinnia ozdorovlenniam dovkillia (metodologiya $i$ praktika) [Economic fundamentals of the environmental sanitation management (methodology and practice)]. Lviv, SI "Lviv Polytechnic", 260 p. (in Ukrainian).

17. Tsigankov, A.P., Melnik, L.G., Yarosh, N.V. (1986). Sovershenstvovanie planirovaniia ispolzovaniia vtorichnyih resursov s uchetom ekologicheskogo faktora [Improved planning of secondary use of resources, taking into account environmental factors]. Tsvetnyie metally, 5, 117-120 (in Russian).

18. Tsigankov, A.P., Yarosh, N.V. (1985). Uluchshenie ispolzovaniia vtorichnyh resursov tsvetnyh metallov [Improving the use of secondary resources of non-ferrous metals]. Planovoe hoziaystvo [Planning Economy], 7, 86-89 (in Russian).

19. Velis, C.A. (2015). Circular economy and global secondary material supply chains. Waste Management \& Research, 33(5), 389-391. Retrieved from doi: 10.1177/0734242X15587641.

20. Vetrova, T.P. (2000). Ekologo-ekonomicheskaia otsenka problemy tverdyh bytovyh othodov v krupnyh gorodah [Ecological and economic assessment of the problem of municipal solid waste in large cities]. Vestnik MGU, Seriya "Ekonomika", 3, 60-73 (in Russian).

21. Zhuk, I.M. (eds.) (2016). Statystychnyi Shchorichnyck Ukrainy v 2015 roci [Statistical Yearbook of Ukraine for 2015]. Kiev, State Statistics Service of Ukraine, 574 p. (in Ukrainian). 